\title{
A PEDAGógIAI MUNKa SZAKMAI FELÜGYELETE AZ EGYESÜLT ÁLLAMOKBAN
}

\author{
Kimmel Magdolna \\ az Eötvös Loránd Tudományegyetem Bölcsészettudományi Karának \\ adjunktusa \\ magdimann@yahoo.com
}

\begin{abstract}
A tanulmány három részre tagolódik: az elsö rész a pedagógia munka szakmai felügyelete jelenleg jellemzö amerikai rendszerének kritikáját összegzi. A második rész a sikeres szakmai felügyelethez szükséges sztenderdeket és a szakmai felügyelet két jó gyakorlatát mutatja be. Végül a harmadik rész arról szól, hogy a szakmai elszámoltathatóság vonatkozásában az USA a tanulói teljesitményekre koncentráló pedagógiai teljesitményértékelési modell felé fordult.
\end{abstract}

Az Egyesült Államok oktatási rendszerének legfőbb sajátossága a decentralizáltság. Az oktatást az alkotmány az egyes államok hatáskörébe utalja, ezért a szövetségi kormány befolyása erősen korlátozott. 1965-ben hoztak először egy, a közoktatást szabályozó szövetségi törvényt, az Elementary and Secondary Education Act-et (Általános és Középiskolai Oktatási Törvény, továbbiakban ESEA) amely az esélyegyenlőség biztosítása érdekében szövetségi pénzalapokat tett hozzáférhetővé az államok és rajtuk keresztül a tankerületek felé. Az oktatás irányítása közvetlenül a tankerületek (School District) kezében van. Az egyes államok különböző mértékben szabályozzák, befolyásolják a tankerületek müködését (Kinney, 2006, 29. o.).

A tanítás minőségéért, így a tanfelügyeletért is a tankerületek felelnek, és ez így van az ESEA utolsó, 2001-ben kétpárti támogatással elfogadott megújítása után is. A megújított törvény, No Child Left Behind (Egy gyermek sem marad le, továbbiakban $N C L B$ ) néven vonult be az amerikai oktatás történetébe. A NCLB törvény egyik legfontosabb alapelve az elszámoltathatóság, ezért a pedagógusi teljesítmények értékelése és ezzel együtt a szakmai felügyelet minősítő szerepe is górcső alá került. Ugyanakkor a tanfelügyeletnek egy másik szerepe, a fejlesztés is kezd elötérbe kerülni, hiszen egyre inkább világossá válik, hogy a tanulói eredmények javításának egyetlen igazán eredményes és költséghatékony módja a pedagógusok szakmai fejlődésének elősegítése. 


\section{A jelenleg folyó szakmai felügyeleti munka kritikája}

A pedagógusok munkáját az Egyesült Államokban az igazgató, nagy tanuló létszámú iskola esetén az igazgató és helyettesei értékelik óralátogatások és a pedagógus órán kívüli teljesítménye alapján, a tankerület által elvárt gyakorisággal, tehát a szakmai felügyeletet nagy valószínúséggel nem a pedagógussal azonos szakos pedagógus végzi.

A szakmai felügyeletnek a pedagógusok munkájának minösitö értékelésével kapcsolatos problémáit legutóbb a The New Teacher Project (Az Új Pedagógus Projekt, a következőkben TNTP) kutatói tárták fel egy négy államra, 12 iskolakerületre, 15000 pedagógusra és 1300 tankerületi és iskolai vezetőre kiterjedő kérdőíves kikérdezés során. (Weisberg et al., 2009) A kutatás során mintegy 40000 pedagógus értékelésének dokumentumait is feldolgozták. Minden érintett államban állami és helyi oktatáspolitikusokból, tankerületi vezetőkből és a pedagógus szakszervezetek képviselőiből álló tanácsadó testületek segítették a kutatókat az adatok értékelésében és az ajánlások megfogalmazásában. A kutatás legfontosabb megállapításai szerint a jelenlegi tanfelügyeleti rendszer

- nem szüri ki a rendszerből a nem megfelelően teljesítő pedagógusokat;

- nem azonosítja a kiváló munkát végzöket;

- nem segíti megfelelően a pályakezdőket;

- és nem biztosít megfelelö kiindulópontot a szakmai fejlesztőmunka számára.

A problémák okait a következökben azonositották:

1. A pedagógusok munkájának értékelései a kutatók által vizsgált tankerületekben csekély számú, az esetek kétharmadában egy-két tanóra látogatására alapozva születnek, és az esetek felében az értékelök még 45 percet sem töltenek egy-egy alkalommal az osztályteremben.

2. Az óralátogatást végrehajtó igazgatók vagy más adminisztrátorok egyáltalán nem vagy nem megfelelően felkészültek a feladatra, ezért nem tudnak megfelelő visszajelzéseket adni a pedagógusok munkájára, így a pedagógusok szakmai fejlesztése sem tud az értékelésekre építeni.

3. Az óralátogatások alapján elkészülö értékelések általánosak, semmitmondóak. A kétfokozatú skálát (megfelelt - nem megfelelt) használó tankerületekben a tanárok 99 százaléka kapott megfelelt minősítést, a többfokozatú skálát használó kerületekben 94 százalékuk a legmagasabb két fokozatba került.

\footnotetext{
${ }^{1}$ A kutatás elsősorban a felügyelet minősítő funkciójára koncentrált, bár a fejlesztő funkció vonatkozásában is tett megállapításokat.
} 
4. A csekély számú 'nem megfelelt' pedagógus esetében a minősítés következményei sokszor nem világosak. Általánosságban elmondható, hogy a már véglegesített pedagógusok eltanácsolása a pályáról olyan nehézkes, hogy ezt sok igazgató meg sem kísérli.

5. A kiváló és a nem megfelelően teljesítő pedagógus óráit ugyanannyiszor látogatják, a két csoport ugyanannyi visszajelzést kap, tehát a szakmai felügyelet nem differenciált (Weisberg et al., 2009, 19-23. o.).

A kutatók végső következtetése az volt, hogy a pedagógusi munka értékelése - legalábbis a vizsgált mintában - puszta formalitás, tehát a szakmai felügyelet nem képes betölteni minősítő szerepét. A kutatási beszámoló azonban arra is rámutatott, hogy a tanfelügyeleti rendszer jelen formájában nem tudja betölteni fejlesztő szerepét sem, mert az értékelések olyan általánosak, homályosak, hogy nem lehet fejlesztési tervet alapozni rájuk.

A felügyeleti munka hiányosságait - úgy minősítő, mint fejlesztő funkciója vonatkozásában - egy volt gyakorló iskolaigazgató, jelenlegi oktatásvezető-képző, aki a problémákat napi munkája során tapasztalta meg, a következőképpen összegzi:

1. Az igazgató egy tanév során általában minden pedagógusának egy óráját látogatja meg, ez alapján pedig lehetetlen képet alkotni az egyes pedagógusok munkájáról.

2. A meglátogatott óra sokszor nem tipikus, mert az elöre bejelentett látogatás alkalmával sok pedagógus 'mintaórát' tart.

3. A felügyelet, az óralátogatás nem a tanulást értékeli, hanem a tanítást, bizonyos előre felállított kritériumok alapján. Az órák megfigyelésének és értékelésének eszközei sokszor nem segítik, hanem akadályozzák a tanítás konstruktív értékelését, mert az előre megadott kritériumok túl merev rendszerbe kényszerítik az értékelöt.

4. A visszajelzések nem elég világosak, a pedagógusok nehezen tudják azonosítani, hogy miben kellene fejlődniük. A kritikai megjegyzések eltűnnek a szóvirágok között, ezért nem lehet az értékelésekre szakmai fejlesztési tervet építeni.

5. Ha az óralátogatás célja a pedagógus munkájának minősítő értékelése, akkor az óramegbeszélések során a pedagógusok defenzívek, hiszen fő céljuk, hogy megvédjék magukat.

6. A tanárok egyéni értékelése felerősíti a hagyományosan magányosan, izoláltan dolgozó pedagógusok elszigeteltségét, mert mindenki a saját 'túléléséért' küzd, ami a teljes tantestület megfelelő szakmai fejlődését akadályozza.

7. A legtöbb igazgató egyszerűen túl elfoglalt ahhoz, hogy a tanári munka felügyeletét, értékelését megfelelő színvonalon el tudja látni (Marshall, 2005, 728-731. o.). 
A gyakorlati szakember tehát saját tapasztalatai alapján hasonló hiányosságokra mutat rá, mint a TNTP kutatói. Bár a szakmai felügyelettel szemben megfogalmazott kritikák elég sötét képet festenek, több olyan, szélesebb körben is elterjedt modell létezik az Egyesült Államokban, amelyben a szakmai felügyelet sikeresen betölti minősítő és fejlesztő szerepét is. A TNTP jelentés szerzői azonosították a hatékony szakmai felügyeleti rendszerek négy legfontosabb jellemzőjét. Nézetük szerint a hatékony szakmai felügyeleti rendszerek értékeléseikben

- különbségeket tudnak tenni a hatékony és a nem hatékony pedagógusok között;

- $\quad$ speciálisan képzett, a pedagógusi munka értékelésére alkalmas szakértőket foglalkoztatnak;

- integrálják a pedagógusi munka értékelését a tanári szakmai fejlődés támogatásával;

- többféle lehetőséget biztosítanak a tisztes visszavonulásra azoknak a pedagógusoknak, akik a folyamatos segítségnyújtás ellenére több minősítő értékelés során sem tudnak javítani teljesítményükön (Eckert, 2009, 2-4. o.).

Ebben az ideális rendszerben a szakmai felügyelet mindkét funkcióját ellátja: megfelelő szakértelemmel értékeli a pedagógus munkáját és a szakmai fejlesztés kiindulópontjául is szolgál.

\section{A szakmai munka sztenderdjei}

A hatékony szakmai felügyeleti rendszert kiépítésének feltétele a pedagógusi munka megfelelö leírása, amelynek segítségével a munka minősége megítélhető. Az USA-ban elöször a veterán pedagógusok ${ }^{2}$ munkájának sztenderdjei születtek meg 1987-ben a National Board for Professional Teaching Standards (Nemzeti Testület a Professzionális Tanítás Sztenderdjeiért, továbbiakban NBPTS) testület munkájának eredményeképpen. Az NBPTS sztenderdjeit ezután a legkülönbözőbb szaktárgyakat tanító pedagógusok munkájára adaptálták. Az NBPTS ezekre támaszkodva az USA minden államában elfogadott önkéntes alapon müködő tanárminősítő rendszert állított fel. Az NBPTS szakértői által minősített pedagógusok nagy presztízsnek örvendenek az Egyesült Államokban.

A 80-as évek végén a Council of Chief State School Officers (az egyes államok közoktatásért felelős fötisztviselöinek szervezete) egy másik projekt keretében a kezdö tanárok értékelésére szolgáló sztenderdek kidolgozását tüzte ki célul. Az 'Interstate New Teachers Assessment Teaching Standards' (INTASC sztenderdek) 1992ben születtek meg (Rotherman és Mead, 2004, 33-35.). Az INTASC sztenderdek

\footnotetext{
${ }^{2}$ Veterán pedagógus: a már nem pályakezdő, gyakorló pedagógusok elnevezése az amerikai szakirodalomban.
} 
felülvizsgálata 2009-2010-ben zajlott le, az új sztenderdeket 2011-ben adták ki (InTASC, 2011).

A fent említett sztenderdek szolgáltak modellként az egyes államok számára, amikor saját sztenderdjeik megalkotására került sor. Ezeken kívül még egy nagy hatású munka született a pedagógusi munka komplexitásának megragadására, leírására: Charlotte Danielson 1996-ban kiadott Enhancing Professional Practice: a Framework for Teaching (A szakmai munka minőségének javítása: a tanítás keretrendszere; a továbbiakban röviden FTT) címü munkája. Danielson az Educational Testing Services (az egyik legismertebb és legnagyobb tesztfejlesztéssel és vizsgáztatással foglalkozó non-profit cég) alkalmazottja volt a 90 -es években. Itt dolgozott az ún. Praxis III teszteken, amelyek a kezdő tanárok tanításának színvonalát volt hivatott felmérni. Ennek a munkának a továbbfejlesztéséből született meg az FTT (Toch és Rothman, 2008, 4-5. o.). Danielson az FTT átdolgozott kiadását 2007-ben publikálta.

Danielson modelljében a pedagógusi munkát négy nagy területre bontotta: tervezés és felkészülés, az osztálytermi környezet, tanítás és szakmai felelösség. A területeken belül további alkotóelemeket azonosított, összesen 76-ot, majd mindegyik esetében leírta, hogy milyen viselkedés jellemzi az adott elemet 'nem megfelelö', 'alapszintü', 'megfelelö' és 'kiváloo' szintet birtokló pedagógust. A cél az volt, hogy mindenki számára kézzelfoghatóvá tegye a tanítás komplexitását, közös nyelvet biztosítson a szakmai párbeszédhez, lehetőséget a pedagógusi munka (ön)értékelésére és a reflexióra (Marzano et al., 2011, 23-24. o.). A modellt vagy változatait ma szerte az Egyesült Államokban használják a pedagógusok munkájának mind fejlesztő, mind minősítő értékelésére. A leírások részletessége, specifikussága lehetővé teszi a pedagógusi munka részletes értékelését, a problémák azonosítását, a szakmai fejlődési lehetőségek kijelölését. Az 1. táblázat egy részletet mutat be Danielson 1996-os értékelési táblázatából, a leírások részletességének érzékeltetésére.

1. táblázat: FTT 3. sz. terület: Utasítások. 3a komponens: A világos és pontos kommunikáció (Heneman és mtsai, 2006, 2. o.)

\begin{tabular}{|c|c|c|c|c|}
\hline \multirow{2}{*}{ Elemek } & \multicolumn{4}{|c|}{ Teljesitési szintek } \\
\hline & Nem megfelelö & Alapszintü & Megfelelö & Kiváló \\
\hline $\begin{array}{l}\text { Utasítások } \\
\text { és eljárások }\end{array}$ & $\begin{array}{l}\text { A tanár utasításai és } \\
\text { eljárásai zavarosak. }\end{array}$ & $\begin{array}{l}\text { A tanár némi zavar } \\
\text { után javítja } \\
\text { utasításait, bár az } \\
\text { utasítások időnként } \\
\text { túl terjengősek. }\end{array}$ & $\begin{array}{l}\text { A tanár utasításai } \\
\text { világosak és elég } \\
\text { részletesek is } \\
\text { a diákok számára. }\end{array}$ & $\begin{array}{l}\text { A tanár utasításai } \\
\text { világosak, és eleve } \\
\text { kiküszöbölik } \\
\text { a lehetséges } \\
\text { félreértéseket. }\end{array}$ \\
\hline
\end{tabular}




\begin{tabular}{|c|c|c|c|c|}
\hline \multirow{2}{*}{ Elemek } & \multicolumn{4}{|c|}{ Teljesitési szintek } \\
\hline & Nem megfelelö & Alapszintü & Megfelelö & Kiváló \\
\hline $\begin{array}{l}\text { Szóbeli és } \\
\text { írásbeli } \\
\text { kommuni- } \\
\text { káció }\end{array}$ & $\begin{array}{l}\text { A tanár beszéde } \\
\text { nem jól hallható, írása } \\
\text { nem jól olvasható. } \\
\text { Beszédében/írásában } \\
\text { nyelvtani és mondat- } \\
\text { szerkesztésbeli hibák } \\
\text { vannak. Szókincse } \\
\text { nem megfelelö, } \\
\text { hibásan, homályosan } \\
\text { fejezi ki magát, } \\
\text { és ezzel zavart kelt. }\end{array}$ & $\begin{array}{l}\text { A tanár beszéde jól } \\
\text { hallható, írása jól } \\
\text { olvasható. Nyelvi } \\
\text { hibákat nem vét. } \\
\text { Szóhasználata } \\
\text { pontos, de szókincse } \\
\text { korlátozott, vagy } \\
\text { nem felel meg } \\
\text { a tanulók életkorának } \\
\text { és hátterének. }\end{array}$ & $\begin{array}{l}\text { A tanár szóbeli és } \\
\text { írásbeli } \\
\text { kommunikációja is } \\
\text { világos és pontos. } \\
\text { Szókincse } \\
\text { megfelel a tanulók } \\
\text { életkorának és } \\
\text { hátterének. }\end{array}$ & $\begin{array}{l}\text { A tanár szóbeli } \\
\text { és írásbeli } \\
\text { kommunikációja } \\
\text { is pontos és } \\
\text { kifejező, olyan } \\
\text { szókincset használ, } \\
\text { amely a tanulást } \\
\text { elősegíti, a tanulási } \\
\text { folyamatot } \\
\text { gazdagítja. }\end{array}$ \\
\hline
\end{tabular}

Míg a Danielson modell és más hasonló leírások a szakmai munka komplexitásának megragadásával eszközt adnak a pedagógusok és a szakfelügyelök/szaktanácsadók kezébe, hogy a pedagógiai munkáról érdemi párbeszédet tudjanak folytatni, ugyanakkor olyan folyamatszervezésre, olyan rendszer kialakítására is szükség van, amely lehetővé teszi a felügyelet minősítő és fejlesztő funkciójának ellátását. A következő részben két ilyen rendszert mutatok be.

\section{A szakmai munka fejlesztő és minősítő értékelésének két rendszere}

\section{TAP: Teacher Advancement Program (Tanári Elömeneteli Program)}

A TAP modellt 1999-ben indította el a Milken Family Foundation, egy magánalapítvány. Azóta a rendszer széleskörüen elterjedt az USA-ban, az alapítvány honlapja szerint a 2011-2012-es tanévben mintegy 20000 tanár dolgozott és 200000 tanuló tanult olyan iskolában, ahol a TAP rendszert alkalmazták ${ }^{3}$. A TAP rendszer négy alapvetésre épül:

- Tanári előmeneteli rendszer kialakítása (multiple career paths). Az elömeneteli rendszer háromfokozatú: 'career' vagyis rendes tanárok, mentortanárok és mestertanárok. Az egyes lépcsőfokokhoz egyre bővülő munkakörök és egyre magasabb követelmények társulnak, igaz, a magasabb pozícióhoz magasabb bér is jár. A mentor- és mestertanárok kiválasztása során vizsgálják tantervi tudásukat, pedagógusi teljesítményüket, és azt is, hogy mennyire képesek hatékonyan együtt dolgozni más felnőttekkel. Az igazgató és helyettesei, a mester és mentortanárok együtt alkotják az iskola eredményességéért felelős iskolavezetést (Leadership Team). Ebben az

\footnotetext{
${ }^{3}$ http://www.tapsystem.org/action/action.taf?page=where Letöltés ideje: 2013. 03. 09.
} 
előmeneteli rendszerben a pedagógus anélkül léphet karrierjének következő lépcsőfokára, hogy feladná a tanítást. A zömmel vezetői és fejlesztői funkciót betöltő mestertanárok is tanítanak, minimum napi két tanórát.

- $\quad$ Állandó szakmai fejlődés (on-going applied professional development): A mestertanárok és/vagy a mentortanárok vezetik az ún. klaszterek, vagyis iskolán belüli tanári csoportok munkáját. Ezek a csoportok vagy az azonos tárgyat tanítókból, vagy az azonos korcsoportot tanítókból alakulnak. Abban a rendszerben, ahol az igazgató feladatai közé tartozik a pedagógiai munka értékelése, támogatása, újdonság, hogy a mester- és mentortanárok az azonos korcsoportot és/vagy tárgyat tanító pedagógusokkal dolgoznak együtt, a gondjaikra bízott pedagógusok munkáját támogatják és értékelik. $\mathrm{Az}$ iskolai órarendet úgy alakítják ki, hogy a tanári csoportoknak legyen heti egy-két órájuk arra, hogy pedagógiai munkájukat és tanulóik eredményeit megvitassák. A pedagógiai fejlesztés irányait és szükségleteit a tanulók eredményei alapján határozzák meg. A mester- és mentortanárok állandó támogatást nyújtanak kollégáiknak. Bemutató órákat tartanak, 'coach-ként' müködnek, órákat látogatnak, óramegbeszéléseket tartanak stb. A szakmai fejlesztő munka tehát állandóan zajlik az iskolai munkába ágyazottan, célzottan, a tanulói eredményekből kiindulva. Ez a rendszer elősegíti a pedagógusok közötti együttmüködést, az együttműködő munkakultúra kialakítását.

- Az oktatásra fókuszáló elszámoltathatóság (instructionally focused accountability): A mester- és mentortanárok évente legalább négy-hat alkalommal értékelik a 'rendes' tanárok munkáját. (A mentor- és mester tanárok munkáját is értékelik, a rendes pedagógusokétól eltérő és még szigorúbb sztenderdek alapján.) A pedagógusok óráit minden tanévben több értékelö, több alkalommal látogatja, részben az objektivitás, részben a megfelelő számú 'mintavétel' okán. A látogatások egy része bejelentett, más része nem. Az értékelők a bejelentett látogatások előtt is beszélnek a pedagógussal, minden látogatás után visszajelzést és szakmai fejlődése érdekében tanácsot adnak. A visszajelzések alapját a TAP huszonhat, a hatékony tanítás ismérveit megfogalmazó, kutatások alapján azonosított sztenderdje alkotja, amelyek mindegyikét öt szinten írták le. (A TAP sztenderdjeit és értékelési táblázatát Danielson FTT modelljére alapozták.) Az óramegbeszélés során azonosítják a fejlesztendő területeket. A mentor- és mestertanárok a teljesítmény javításához hatékony támogatást nyújtanak, például bemutató órát tartanak, vagy együtt tanítanak (team-teaching) a kollégával. Az óralátogatások nem következmény nélküliek, ugyanis ebben a rendszerben a pedagógusoknak minden évben meg kell újítaniuk müködési engedélyüket. A tanév végi minősítő értékelést azonban négy-hat formatív értékelés előzi meg, vagyis minden pedagógus lehetőséget kap arra, hogy 
a tanév során javítson a teljesítményén, és így a végső, minősítő értékelés elégséges számú látogatásra, adatra épül.

- Teljesítmény-alapú bérezés (performance-based compensation): A tanári fizetés differenciált. A rendes tanárok fizetése osztálytermi munkájuk értékelésétől, a diákjaik eredményéhez általuk 'hozzáadott pedagógiai értéktől', és a teljes tantestület által az iskola összes tanulója eredményéhez 'hozzáadott pedagógiai értéktöl' függ. A mentor és mestertanárok az alapfizetésük mellett extra feladataik ellátásáért külön díjazásban részesülnek.

A TAP rendszerben a pedagógusi munka fejlesztő-minősító értékelését végzőket felkészítik az értékelési munkára. Az értékelők csak a képzés sikeres elvégzése után végezhetnek felügyeleti munkát és felügyeleti engedélyüket évente meg kell újítaniuk. ${ }^{4}$ (Toch és Rothman, 2008; Little, 2009)

A TAP rendszer megfelel a TNTP által meghatározott mindegyik alapelvnek: különbséget tesz a teljesítmények különböző szintjei között, képzett mentorok és mestertanárok támogatják és értékelik a pedagógusokat, állandó szakmai fejlödési lehetőségeket biztosítanak számukra. A támogatás ellenére nem megfelelően teljesítő pedagógusok a tapasztalatok alapján általában önként távoznak a rendszerböl (Eckert, 2009, 4. o.).

\section{PAR: Peer Assistance and Review (Társ-segitö és Értékelési rendszer)}

A Társsegítő és Értékelési Program (Peer Assistance and Review, továbbiakban PAR) lényege, hogy tapasztalt, kiváló és a felügyeleti munkára felkészült tanárok, ún. 'Tanácsadó Tanárok' (Consulting Teachers) nyújtanak segítséget a pályakezdö pedagógusoknak, vagy veterán, de nehézségekkel küzdő kollégáknak. A modellt első alkalommal az ohio-i Toledoban alkalmazták, 1981-ben, Dal Lawrence szakszervezeti vezető ajánlására. A tanácsadó tanárokat a tankerület három-öt évre felmenti az osztálytermi munkavégzés alól, majd a tanácsadói szerződés lejárta után visszamennek tanítani. A tanácsadók bére magasabb, mint az osztályteremben dolgozó kollégáiké, a tankerület lehetőségeitől függően évente 3-10 ezer dollárral (Johnson et al., 2010, 13. o.).

A modell tankerületi szinten müködik. Vezető testületébe a tankerület, vagyis a munkáltató és a pedagógus szakszervezet(ek), vagyis a munkavállalók képviselői ülnek, ez az ún. PAR Panel. Ennek a testületnek számolnak be munkájukról a tanácsadó tanárok és teszik meg javaslataikat a kezdő, illetve a problémákkal küszködő veterán tanárok további foglalkoztatásával kapcsolatban. A tanácsadók meghallgatása és a dokumentumok megtekintése után a PAR Panel dönt a további foglalkoztatásról. (Johnson et al., 2010, 5. o.). Mielőtt azonban ilyen horderejü

\footnotetext{
${ }^{4}$ http://www.tapsystem.org Letöltés ideje: 2013. 03. 09.
} 
döntésre tenne javaslatot, a tanácsadó tanár egy, sőt esetleg két tanéven át intenzív segítséget nyújt a gondjaira bízott pedagógusnak. Egy-egy tanácsadó tanárhoz általában 10-20 pedagógus tartozik. A tanácsadó rendszeresen, évente akár 10-20 alkalommal is meglátogat egy-egy pedagógust, és az óralátogatások után mindig ad visszajelzést, tanácsot. Ezen kívül feladatai a következők:

- egyéni fejlődési terv kidolgozása minden gondjaira bízott pedagógussal,

- közös óratervezés,

- bemutató óra tartása,

- tanítási anyagok és más segédeszközök biztosítása,

- óralátogatások szervezése (Johnson et al., 2010, 13. o.).

A $P A R$ rendszerben a tanácsadó tanárokhoz lehetőség szerint velük azonos szakos, azonos korcsoportot oktató pedagógusokat osztanak be, így a tanácsadás értelemszerüen sokkal hathatósabb, az értékelés a pedagógusok számára sokkal hitelesebb, mintha az iskolavezetés végezné. (Ne feledjük el azonban, hogy ebben a rendszerben a veterán tanárok munkájának felügyelete és értékelése továbbra is az igazgató feladata. Ö dönt arról, hogy a nem megfelelöen teljesítő veterán pedagógust a PAR rendszer gondjaira bízza-e.)

A PAR rendszer sikere elsősorban a tanácsadók kiválasztásán és képzésén múlik. A kiválasztás többfordulós, nyílt pályázaton történik. Csak az pályázhat, akinek több éves - tankerületenként változó, általában öt-hét éves - pedagógusi gyakorlata van. A pályázathoz szükséges az igazgató és még egy kolléga ajánlása. Ezután kerül sor a pályázó óráinak sokszor előre nem bejelentett meglátogatására, majd a harmadik fordulóban az PAR Panel előtti interjúra. Aki mindhárom akadályt sikeresen veszi, azzal szerződést kötnek.

A kiválasztott pedagógusokat ezután kiképezik a feladatra. A képzés tartalma és hossza tankerületenként változó. A legtöbb esetben elismert külső képző szervezetek intenzív nyári kurzust tartanak a leendő tanácsadóknak, de a képzés részét képezi a már múködő tanácsadókkal folytatott eszmecsere is. Van olyan tankerület, ahol már müködő tanácsadó munkájának megfigyelése, nyomon követése (shadowing) is a képzés része. A már müködő tanácsadók minden tanév során többször találkoznak, megvitatják problémáikat, tehát támogatják egymást a felügyeleti-tanácsadói munkában (Johnson et al., 2010, 17-18. o.).

A PAR modell legátfogóbb vizsgálatára egy kaliforniai városi tankerületben került sor. Goldstein (2007, idézi Little, 2009, 8. o.) négy éven keresztül kísérte figyelemmel a tankerület $P A R$ programját. A rendszer egyik legnagyobb előnyét a megosztott vezetői felelösségben látta: a tanácsadó tanárok sok terhet levettek az iskolavezetés válláról, hiszen előtte az óralátogatás az iskolavezetés feladata volt. A vizsgált tankerületben a $P A R$ rendszer betöltötte minősítő feladatát, mert a rendelkezésre álló adatokból megállapítható volt, hogy több szerződésbontás történt itt, mint a más tanári teljesítményértékelő rendszert alkalmazó tankerületekben. 
Ugyanakkor a kutatás arra is rámutatott, hogy a kezdő tanárok számára nagy segítség a gyakori látogatás és visszajelzés, az intenzív kapcsolattartás egy segítő kollégával. A $P A R$ rendszer segítségnyújtása folytán több kezdő tanár maradt a pályán, mint a más rendszert alkalmazó tankerületekben. Goldstein kutatása rávilágított azokra a tényezőkre is, amelyek a $P A R$ rendszer sikeréhez szükségesek: a legfontosabb ezek közül a körültekintő bevezetés. A tanácsadó tanárokat nagyon körültekintően kell kiválasztani, az értékelési sztenderdeket pedig minden érintett pedagógusnak meg kell ismernie és el kell fogadnia. Johnson és munkatársai ezen kívül még azt is megemlíti, hogy a rendszer előnyeiről az igazgatókat is meg kell győzni, mert sokan közülük kompetenciájuk megnyirbálásaként élik meg a tanácsadók megjelenését (Johnson et al., 2010, 15. o.).

A $P A R$ rendszer nagy hiányossága, hogy az iskolavezetők által megfelelőnek minősített veterán pedagógusok számára nem áll rendelkezésre, így nem a teljes pedagógusi állomány munkáját támogatja. Viszont a TNTP által azonosított legtöbb vonással rendelkezik: differenciált segítséget nyújt a pedagógusok számára, hiszen elsősorban a kezdő és a nem megfelelően teljesítő veterán tanárokat célozza meg. Megfelelően kiválasztott és képzett szakemberek állandó, intenzív szakmai fejlesztési munkát végeznek a gondjaikra bízottakkal. A kiváló pedagógusokat nem azonosítja, de a nem megfelelően teljesítők számára valós lehetőséget nyújt teljesítményük javítására. Ha a felzárkózás a támogatás, segítségnyújtás ellenére nem történik meg, akkor a tanácsadó javaslata alapján a tankerületi vezetés számára könnyebb a döntéshozatal, hiszen elég sok adat alapján hozhatják meg döntésüket a pályáról történő eltanácsolásról. A rendszer további előnye, hogy a kiváló pedagógusok számára lehetőséget nyújt a szakmai előrelépésre, a tanácsadói pozíció megszerzésére, anélkül, hogy örökre el kellene szakadniuk az osztálytermi munkától.

\section{A szakfelügyeleten túl: a pedagógusi munka értékelése a tanulói teljesítmények alapján}

Az NCLB alapfilozófiája az volt, hogy ha a pedagógusok azt állítják, hogy a tanítás minősége döntő fontosságú a tanulók fejlődése szempontjából, akkor a tanulók előrehaladásának mérése a pedagógusi munka minőségének legjobb mércéje. Ezért a pedagógusi teljesítmények értékelése során elsősorban a tanulói teljesítmények mérésére összpontosítottak, vagyis a szakmai elszámoltathatóság tanulói teljesítménymérésen alapuló rendszerét választották (Radó, 2007).

Ahhoz, hogy a tanári teljesítmények a tanulói eredményeken keresztül mérhetők legyenek, elöször meg kell fogalmazni, mit kell tudniuk és mit kell tudniuk megcsinálni a tanulóknak az egyes évfolyamok végére az egyes tantárgyakból, majd le kell írni a követelmények teljesítésének lehetséges szintjeit, vagyis meg kell alkotni az egyes tantárgyak sztenderdjeit. Ezután szükség van olyan mérőeszközök kifejlesztésére, amelyek képesek objektíven mérni, hogy a tanulók elsajátí- 
tották-e a sztenderdekben megfogalmazott tudást, és birtokában vannak-e a sztenderdekben leírt készségeknek. A $N C L B$ bevezetése után az államok óriási összegeket fektettek ezeknek a mérőeszközöknek a kialakítására matematika és anyanyelv tárgyakból - az NCLB ezekből a tárgyakból tette kötelező az évenkénti felmérést a 3-8 évfolyamokon - és a mérések lebonyolítására. Ezekkel a tesztekkel és mérésekkel, valamint az $N C L B$ törvény egyéb elöírásaival szemben, amelyek az iskolák és a pedagógusok elszámoltatását célozták, rengeteg kifogás merült fel, amelyek ismertetése kívül esik e tanulmány keretein ${ }^{5}$.

A felvetődött problémák ellenére a pedagógusok szakmai munkájának minősítésében a tanulói teljesítmények kulcsszerepet játszanak. Például Colorado államban nagyszabású reform kezdődött 2010-ben, a SB-10-191 törvény elfogadásával. A reform elsődleges célja a pedagógiai munka értékelésének átalakítása. A reform 50 százalékban a tanulói teljesitményektöl, 50 százalékban pedig az óralátogatások eredményeitől, vagyis a szakmai felügyelet értékelésétől teszi függővé, hogy az adott pedagógus a négy lehetséges teljesítmény kategória közül melyikbe kerül ${ }^{6}$.

A tanulói teljesítménymérés tehát a pedagógiai munka értékelésének egyik fontos pillérévé vált, és ezért most már inkább csak a teljesítménymérés módszertanával kapcsolatban felmerült kifogásokat igyekeznek orvosolni. Az egyik kifogás a tanulói teljesítménymérések ellen az, hogy kritériumorientált teszteket alkalmaznak, amelyek az egyes tanulói teljesítményeket az állam által célként kitüzött tudás- és készségszinthez mérik. Ezek a mérések azonban nem tükrözik megfelelően a tanulók valós teljesítményét, hiszen például az alacsonyabb szintröl induló tanulók mégoly nagyarányú teljesítményjavulását sem ismerik el, ha a tanulóknak az elvárt szintet nem sikerül elérniük, és így persze a tanulói teljesítményjavulás mögött álló pedagógusi munka sem nyer elismerést. Ezért kapnak egyre nagyobb teret a tanári munka által a tanulók teljesítményéhez hozzáadott pedagógiai érték kiszámítását célzó modellek. (ValueAddedModels, a továbbiakban VAM). ${ }^{7}$

Többféle $V A M$ statisztikai program is forgalomban van, közös vonásuk, hogy egy-egy pedagógus tanulóinak teszteredményeit hosszabb időn át követik. Az eredmények alapján a tanár tanulói által elért, a teszteredményekben megmutatkozó fejlődési mutatót, a 'hozzáadott értéket' vagyis az adott tanár tanulóira gyakorolt hatását megbecsülik, és összevetik más tanárok hasonló mutatójával, és így az átlaghoz

\footnotetext{
${ }^{5}$ A NCLB törvényről és bevezetésének tanulságairól lásd például magyar nyelven Kinney (2006) cikkét, angol nyelven Hess és Finn (2007), Meier és Wood (2004) tanulmányköteteit, vagy a Rand Corporation 2007-es jelentését. A tanulói teljesítmények mérésén alapuló elszámoltathatóságról angol nyelven lásd Hamilton (2003) összefoglalóját, vagy Tóth (2010) magyar nyelvü áttekintését.

${ }^{6}$ A 2012-2013-as tanévben a terveknek megfelelően a kipróbálás zajlik, a reformok teljes körü bevezetésére a 2014-2015-ös tanévtől lehet számítani (StateCouncil... 2011).

${ }^{7}$ Magyarországon is végeztek számításokat a hozzáadott pedagógiai érték megállapítására az országos kompetenciamérések kapcsán, lásd például Vári és Mátrai (2006). A témáról ma is folyik szakmai diskurzus, például Radó Péter blogbejegyzése nyomán:

http://oktpolcafe.hu/a- hozzaadott-ertekrol-miert-is-kell-integralni-1831 Letöltés ideje: 2013. 04. 12.
} 
képest gyengébb és jobb pedagógusi teljesítményeket is azonosítják. A programok nagy előnye, hogy a 'hozzáadott érték' kiszámolásánál több-kevesebb háttértényezőt is figyelembe vesznek, például az iskolai kontextust, a tanulók szociokulturális hátterét stb. A tanulói teljesítményeket befolyásoló összes tényezőt azonban ezek a programok sem tudják figyelembe venni. Az egyetlen statisztikai szempontból kielégítő megoldás az lenne, ha a tanárokat és tanulócsoportokat véletlenszerúen rendelnék egymáshoz, ebben az esetben a tanulói teljesítményben kimutatható különbségek nagy valószínüséggel tényleg a pedagógus munkájának lennének betudhatók. Erre azonban a valóságban nincs mód (Braun, 2005, 10. o.).

A VAM programok által kiszámított hozzáadott pedagógiai érték sem tekinthető tehát a pedagógus hatékonysága abszolút mutatójának, ennek a módszernek is megvannak a maga korlátai (Goldhaber, 2010; Lomax és Kuenzi, 2012). A programok alkalmazása ennek ellenére terjed. A pedagógiai hozzáadott értékkel számol például a fentebb leírt TAP rendszer is: a pedagógusok munkájának értékelésekor 50 százalékban az óralátogatások eredményeit, 30 százalékban a pedagógus által az egyes gyermekek fejlődéséhez 'hozzáadott értéket', 20 százalékban pedig a teljes tantestület által az iskola összes tanulója fejlődéséhez 'hozzáadott értéket' veszi figyelembe.

A pedagógusi teljesítmény tanulói teljesítmények tükrében történő vizsgálatának, így a 'hozzáadott pedagógiai érték' vizsgálatának legnagyobb hozadéka azonban a szakmai fejlesztés szempontjából lenne várható. A módszer részben segíthet a fejlesztésre, támogatásra szoruló iskolák, pedagógusok azonosításában és a fejlesztésre csak korlátozottan rendelkezésre álló erőforrások célzott felhasználásában. Ennél is fontosabb azonban, hogy a tanulói eredmények vizsgálata a pedagógusokat arra ösztönözheti, hogy a 'letanítás' helyett a tanulási folyamatra és a tanulókra összepontosítsanak (Marzano et al., 2011, 27. o.). Ha pedig az egész tantestület teljesítményének megítélésében is szerepet kap a 'hozzáadott érték', a nem kielégítő eredmények arra ösztökélhetik a pedagógusokat, hogy együtt dolgozzanak a hiányosságok feltárásán, a szakmai munka javításán. Az együttmüködő szakmai közösségekben rejlö 'felhajtóerő' hatékonysága pedig feltehetően vetekszik bármely szakmai felügyelet hatékonyságával.

\section{Összefoglalás}

Az Egyesült Államokban a pedagógiai munka minősítő célú értékelése, a pedagógusok elszámoltathatóságának előtérbe kerülése miatt, kitüntetett figyelmet kapott a közoktatási törvény 2001-es megújítása után. A pedagógusok munkájának minősítésében azonban elsősorban nem a szakmai felügyeletre, hanem a tanulók elörehaladásának mérésére építettek. 2001 óta az is kiderült, hogy a pedagógusok szakmai fejlesztése, és így a felügyeleti munka fejlesztő funkciója legalább olyan fontos, hanem fontosabb, mint minősítő funkciója, mert ez ad lehetőséget az oktatás színvonalának 
legolcsóbb és legtartósabb emelésére. A cikkben ismertetett jó gyakorlatok is elsősorban a pedagógusok munkájának támogatását állították a középpontba.

Úgy tűnik, hogy az amerikai oktatásban a pedagógusok munkájának tanulóik elért eredményein keresztüli minősítő értékelése annak ellenére része marad a rendszernek, hogy a szakma tisztában van a tanulói teljesítményeket mérő tesztek tökéletlenségeivel, és a tanulói eredmények változásait a pedagógusok munkájához kötő modellek hiányosságaival is. A tanulói eredmények górcső alá vétele azonban nem csak a minősítésben, hanem a fejlesztő munkában is szerepet kaphat: a tanulókért, előrehaladásukért felelősséget viselő tantestületet a tanulók sztenderdizált teszteken elért eredményeinek alapos vizsgálata arra ösztökélheti, hogy együttesen, egymást támogatva javítson pedagógiai gyakorlatán.

\section{Irodalom}

Braun, H. I. (2005): Using Student Progress To Evaluate Teachers: A Primer on ValueAdded Models. Policy Information Center, ETS: Princeton, NJ.

Danielson, C. (1996): Enhancing Professional Practice: a Framework for Teaching. Association for Supervision and Curriculum Development. Alexandria, VA.

Eckert, J. (2009): More thanWidgets. TAP: A Systemic Approach to Increased Teaching Effectiveness. National Institute for Excellence in Teaching. http://www.tapsystem.org/publications/ffo_rpts_eckert.pdf Letöltés ideje: 2013. 03. 09.

Goldhaber, D. (2010): When the Stakes Are High, Can We Rely on Value-Added? Exploring the Use of Value-Added Models to Inform Teacher Workforce Decisions. Center for American Progress, Washinton D.C.

http://www.americanprogress.org/issues/education/report/2010/12/01/8720 Letöltés ideje: 2013. 04. 08.

Hamilton, L. (2003): Assessment as a Policy Tool. Review of Research in Education. Vol. 27. 25-68.

Heneman, H. G. III - Milanowski, A. - Kimball, S. M. - Odden, A. (2006): StandardsBased Teacher Evaluation as a Foundation for Knowledge- and Skills-Based Pay. University of Pennsylvania, Consortium for Policy Research in Education, Policy Brief May, RB-45. http:/www.cpre.org Letöltés ideje: 2010.01.20.

Hess, F. M. - Finn, Ch. E. (eds. 2007): 'No remedy left behind: lessons from a half decade of NCLB'. The AIS Press, Washington D.C.

InTASC Model CoreTeachingStandards: a Resource for StateDialogue. (2011), Washington, D.C.: CCSSO.

Johnson, S. M. - Papay, J. P. - Fiarman, S. E. - Munger, M. S. - Qazilbash, E. K. (2010): Teacher to Teacher. Realizingthe Potential of Peer Assistance and Review. Harvard GraduateSchool of Education. Center for American Progress.

http://www.americanprogress.org/wp-content/uploads/issues/2010/05/pdf/par.pdf Letöltés ideje: 2013. 03. 10.

Kinney, M. B. (2006): A No ChildLeft Behind közoktatási törvény az USA-ban: Mit tanultunk négy év alatt? Magyar Pedagógia, 1. sz. 29-42. 
Little, O. (2009): Teacher Evalution Systems. The Window for Opportunity and Reform. National Education Association.

http://www.nea.org/assets/docs/2009teacherevaluationsystems.pdf Letöltés ideje: 2010. február 2.

Lomax, E. D. - Kuenzi, J. J. (2012): Value-Added Modelling for Teacher Effectiveness. Congressional Research Service. http://www.fas.org/sgp/crs/misc/R41051.pdf Letöltés ideje: 2013. 04. 08.

Marshall, K. (2005): It's Time to RethinkTeacher Supervision and Evaluation. Phi Delta Kappan June 2005, 86 (10):727-735. http://myboe.org/cognoti/content/file/resources/documents Letöltés ideje: 2013. 03. 06.

Marzano, R. J. - Frontier, T. - Livingstone, D. (2011): Effective Supervision: Supporting the Art and Science of Teaching. ASCD: Alexandria, VA.

Meier, D. - Wood, G. (eds., 2004): Many Children are Left Behind. The Forum for Education and Democracy, Boston, Mass.

Radó Péter (2007): A szakmai elszámoltathatóság biztosítása a magyar közoktatásban. Új Pedagógiai Szemle, 12. sz. 3-39.

Rand Corporation (2007): State and Local Implementation of the No Child Left Behind Act. A report from the National Longitudinal Study of No Child Left Behind. www.rand.org Letöltés ideje: 2013. 03. 28.

Rotherham, A. J. - Mead, S. (2004): Back totheFuture: The History and Politics of State Licensure and Certification. In: Hess, F. M. - Rotherham, A. J. - Walsh, K.: A Qualified TeacherinEveryClassroom. Appraising Old Answers and New Ideas. Cambridge, Ma.: Harvard Education Press, pp. 11-47.

State Council for Teacher Effectiveness Report and Recommendation. 2011. http://legisweb.state.wy.us/InterimCommittee/2012/SCEEReports.pdf Letöltés ideje: 2013. 01. 02.

Toch, T. - Rothman, R. (2008): Rush to Judgment: Teacher Evaluation in Public Education. An Education SectorReport.

http://www.educationsector.org/sites/default/files/publications/RushToJudgment_ES_J an08.pdf Letöltés ideje: 2013. 03. 06.

Tóth Edit (2010): Tesztalapú elszámoltathatóság a közoktatásban. Iskolakultúra, 1. sz. 60-75.

Vári Péter - Mátrai Zsuzsa (2006): Mitől jó az iskola? A hozzáadott pedagógiai érték számításának jelentősége az országos kompetenciamérésben. In: Kelemen Elemér - Falus Iván (szerk.): Tanulmányok a neveléstudomány köréből. Müszaki Könyvkiadó, Budapest, 263-282.

Weisberg, D. - Sexton, S. - Mulhern J. - Keeling, D. (2009): The Widget Effect: Our National Failure to Acknowledge and Act on Differences in Teacher Effectiveness. 2nd edition. http://widgeteffect.org/downloads/TheWidgetEffect.pdf Letöltés ideje: 2013. 03. 06.

http://oktpolcafe.hu/a- hozzaadott-ertekrol-miert-is-kell-integralni-1831 Letöltés ideje: 2013. 04. 12.

http://www.tapsystem.org Letöltés ideje: 2013. 03. 09. 